IbBertson, H. K., and O'Brien, K. P. (1962): Adrenal Autografts in Treatment of Cushing's Disease, Brif: med. J., ii, 703 .

JaILER, J. W. (1953): Virilism, Bull. N.Y. Acad. Med., 29, 377.

KLOPPER, A., Michie, E. A., and Brown, J. B. (1955): A Method for the Determination of Urinary Preg电 nanediol, J. Endocr.. 12, 209.

KoRNEL, L. (1959): An Improved, Rapid Method for Free and Conjugated 17-hydroxycorticosteroids in Urine, Metabolism, 8, 432.

Lamp-Hintzen, D. A. V. M., and Huis iN't Veld, L. G. (1955): Atypical Porter-Silber Reaction after the Administration of Sulfamerazine, J. clin. Endocr., 15, 1152.

LipSETT, M. B., and Wilson, H. (1962): Adrenocortical Cancer: Steroid Biosynthesis and Metabolism Evalu $\overline{\bar{\sigma}}$ ated by Urinary Metabolites, J. clin. Endocr., 22, 906.

MarKS, L. J., and LefTIN, J. H. (1954): A Note of Caution on the Lack of Specifity of the Porter-Silbe Reaction for 17, 21-dihydroxy-20-ketosteroids, J. clin. Endocr., 14, 1263.

Moxham, A., and Nabarro, J. D. N. (1956): Urinary Glucocorticoid Excretion, J. clin. Path., 9, 351.

Patterson, J. (1947): Diagnosis of Adrenal Tumours, Lancet, ii, 580.

PorTer, C. C., and Silber, R. H. (1950): A Quantitative Color Reaction for Cortisone and Related 17, $21:$ dihydroxy-20-ketosteroids, J. biol. Chem., 185, 201.

Ross, E. J. (1961): The Adrenal Medulla, the Adrenal Cortex, Sodium and Blood Pressure, Proc. roy. Soç Med., 54, 1005. Silber, R. H., and Porter, C. C. (1954): The Determination of 17, 21-dihydroxy-20-ketosteroids in Urine
and Plasma, J. biol. Chem., 210, 923.

Soffer, L. J., Dorfman, R. I., and Gabrilove, J. L. (1961): The Human Adrenal Gland, p. 417, London $\vec{b}$ Henry Kimpton.

Soffer, L. J., LeSNick, G., Sorkin, S. Z., SOBOtKa, H., and JACOBS, M. D. (1944): The Utilization of Intra含 venously Injected Salt in Normals and in Patients with Cushing's Syndrome before and after Administrais tion of Desoxycorticosterone Acetate, J. clin. Invest., 23, 51.

SOFfer, L. J., GABRILOve, J. L., and JACOBS, M. (1949): Further Studies with the Salt Tolerance Test in Normal Individuals and in Patients wih Adrenal Cortical Hyperfunction, J. clin. Invest., 28, 1091.

Symington, T.: Personal Communication.

Van De Wiele, R., Christy, N. P., Lieberman, S., and Jailer, J. W. (1958): Cushing's Syndrome. IVD Urinary 17-ketosteroids in Patients with Adrenocortical Tumours (24405), Proc. Soc. exp. Biol. (N.Y.) 99, 520.

Wilkins, L. (1962): Congenital Virilizing Adrenal Hyperplasia, Arch. Dis. Child., 37, 231.

Wilkins, L., GardNer, L. I., CRIGLER, J. F., Jr., Silverman, S. H., and MigeON, C. J. (1952): Further Studies on the Treatment of Congenital Adrenal Hyperplasia with Cortisone. (1) Comparison of Oral flo Intramuscular Administration of Cortisone with a Note on the Suppressive Action of Compounds $F$ a B on the Adrenal, J. clin. Endocr., 12, 257.

WiLkinson, D. S. (1961): Betamethasone, Brit. med. J., i, 1319.

Williams, R. H. (1962a): Textbook of Endocrinology, Third Edition, p. 89. Philadelphia and London: W B. Saunders Company.

WiLliams, R. H. (1962b): ibid, p. 367.

B. Saunders Company.

Williams, R. H. (1962c): ibid, p. 364.

\title{
MENINGISM AND PITUITARY COMA
}

J. M. S. PearCe, M.B., M.R.C.P.*

Registrar in Neurology

J. I. BALla, M.B., M.R.C.P.(Ed.)

Registrar in Neurology

From the Regional Neurological

Non-iatrogenic hypopituitarism usually results from one of two pathological processes, postpartum pituitary necrosis (Sheehan \& Summers, 1949) or pressure upon the secretory cells of the gland by tumour tissue. The former condition presents with features of adrenal, thyroid and gonadal hypofunction; the latter is manifest by a combination of these signs of hypopituitarism accompanied by visual failure due to chiasmal compression. Less commonly the first indication of pituitary failure is the clinical state described as pituitary coma. Disturbance of consciousness in hypopituitarism may be due to hypoglycæmia, hypotensive fainting attacks, acute adrenal crisis, myxœdema coma, and water intoxication. The
IRIS SWANSON, M.B., B.S. Senior House Officer

J. B. Foster, M.B., M.R.C.P. Consultant Neurologist

Centre, Newcastle-ujon-Tyne.

onset of impaired consciousness is commonly pre cipitated by operation (particularly those involving the skull), by infection, or the inadvertent adminis tration of narcotics, insulin or intravenous fluids These features are frequently superimposed upor those of chronic pituitary failure, that is dry skina loss of axillary and pubic hair, vulval atrophy, pallor and puffiness of the face. However, these signs may be minimal in degree and therefore easily overlooked. Various reviews of the subject5 have been written by Sheehan and Summers (1949, 1952), Farquharson (1950), Allott an\& Simmons (1951), Ingraham, Matson and McLauriw (1952), Perkins and Rynearson (1952), Caughey and Garrod (1954), and Caughey (1958).

*Present address: Senior Registrar, Dept. of Neurology, The General Infirmary, Leeds 1. 
We have recently observed a patient with hypopituitarism who presented with the clinical features of a meningitic illness. This unusual presentation is a potential source of diagnostic confusion and is thought to be worthy of recording in detail.

\section{Case Report}

A married woman aged 44 was admitted to hospital with a twelve-hour history of increasing tiredness and feeling cold. She retired to bed and was later found restless, confused and groaning. Her skin felt very hot. Examination in hospital at this stage revealed an ill-looking, extremely restless, semi-comatose woman with a temperature of $103^{\circ} \mathrm{F}$. There was marked neck stiffness but no focal neurological signs were found.

A clinical diagnosis of meningitis was made but examination of the cerebro-spinal fluid did not substantiate this: (protein $60 \mathrm{mg}$., sugar $60 \mathrm{mg}$ / $100 \mathrm{ml}$., cells: 5 lymphocytes/cu. $\mathrm{mm}$.). The patient was given antibiotics and intragastric glucose fluids. During the following twenty-four hours no obvious improvement occurred and she was transferred to the Regional Neurological Centre. On arrival the patient was found to have temperature of $103^{\circ} \mathrm{F}$., marked cerebral irritation, mild dehydration and marked neck stiffness. The blood pressure was $90 / 60 \mathrm{~mm}$. Hg. and scattered rales were heard at both lung bases. She was pale with fine, dry skin, and over both shins were a number of tissuepaper scars. Pubic and axillary hair was absent and the vulva was atrophic. The optic fundi showed no abnormality. In the upper limbs the tone was increased and the tendon reflexes were brisk. In the lower limbs the deep tendon reflexes were unobtainable: both plantar responses were flexor.

At this stage the skull and chest $\mathrm{X}$-rays were found to be normal. Examination of the peripheral blood showed: $\mathrm{Hb}, 15 \mathrm{~g} . / 100 \mathrm{ml}$. w.b.c., $13,000 /$ per cu. mm.: ESR $54 \mathrm{~mm}$./hr. Lumbar puncture: CSF pressure normal, protein $42 \mathrm{mg} / 100 \mathrm{ml}$ : : cells, 6 lymphocytes/cu. $\mathrm{mm}$. The EEG showed a generally slow record with a gross excess of slow rhythmical delta activity in both frontal regions, suggesting a projected discharge frrom some primary disturbance in the midline structures. The patient was given antibiotics and rectal saline infusion.

A few hours after admission a more detailed history became available from the husband. Sixteen years before (at the age of 28 years) at the birth of her fifth child, she had a retained placenta and a severe postpartum hæmorrhage. She had been delivered at home and needed resuscitation and transfusion by the local flying squad. She was apparently unconscious for a few hours. Several days later she developed ulcers on both shins. She failed to lactate, had persisting amenorrhoea, and remained very pale and lethargic. She lost weight, the axillary and pubic hair fell out and the patient became intolerant of the cold. In recent years the patient has had attacks of anorexia, extreme lethargy and confusion lasting two to three days. These episodes have usually been precipitated by a trivial upper respiratory tract infection. Investigations carried out in 1952, (routine flying squad follow-up) showed the patient to be clinically and biochemically hypopituitary. BMR minus 13 per cent; the $24 \mathrm{hr}$. urinary $17 \mathrm{KS}$ excretion $1.5 \mathrm{mg}$.: a glucose tolerance curve showed a fasting blood sugar of $20 \mathrm{mg} . / 100 \mathrm{ml}$. followed by values of $53,50,50,45,45$, at halfhour intervals after $50 \mathrm{~g}$. of glucose. The patient at this time refused further follow-up appointments and treatment was never instituted.

On obtaining this history a provisional diagnosis of hypopituitary coma was made, but specific therapy was withheld because the patient appeared to be making a spontaneous recovery. On the following morning (12 hours after admission) the patient had so improved that neck stiffiness was no longer evident, she was afebrile and quite rational. She confirmed the history outlined above.

Investigations. Skull and chest radiographs were normal, and culture and microscopy of urine and stools were negative. Serum electrolytes: $\mathrm{Na}$. 139: K. 3.4; Cl. 95; Carbon dioxide $20 \mathrm{mEq} / 1$. Blood urea, $61 \mathrm{mg} . / 100 \mathrm{ml}$. Blood sugar, after 48 hours fast (after recovery) $39 \mathrm{mg} . / 100 \mathrm{ml}$., in the absence of hypoglycæmic symptoms. Glucose tolerance test after $50 \mathrm{~g}$. oral glucose, $60,127,79,73,106,84$ $\mathrm{mg} / 100 \mathrm{ml}$. at 30 minute intervals.

TABle I Tests of Thyroid Function

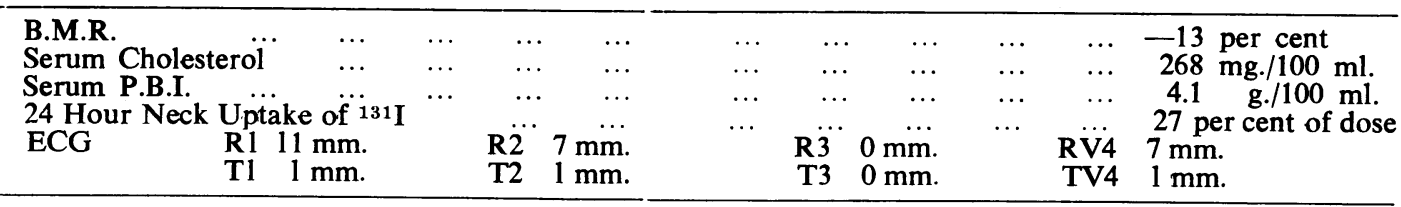

TABLE II Tests of Pituitary Adrenal Function

\begin{tabular}{|c|c|c|c|c|c|}
\hline \multirow{2}{*}{$\begin{array}{l}\text { Basal Plasma Cortisol } \\
\text { Basal } 24 \text { hour urine }\end{array}$} & & \multicolumn{4}{|c|}{$2.0 \mu \mathrm{g}$. per $100 \mathrm{ml}$} \\
\hline & $\begin{array}{l}17 \mathrm{KS} \\
17 \mathrm{OHCS}\end{array}$ & $\begin{array}{l}0.85 \\
4.0\end{array}$ & $\begin{array}{l}0.88 \\
3.0\end{array}$ & $\begin{array}{l}2.07 \\
2.3\end{array}$ & $\begin{array}{l}\text { mg./ } \\
24 \text { hours }\end{array}$ \\
\hline ACTH $3 \times 80$ units & $\begin{array}{l}17 \mathrm{KS} \\
17 \mathrm{OHCS} \\
\end{array}$ & $\begin{array}{l}1.7 \\
4.1\end{array}$ & $\begin{array}{l}1.6 \\
1.2\end{array}$ & $\begin{array}{l}2.7 \\
0.7\end{array}$ & $\begin{array}{l}\text { mg./ } \\
24 \text { hours }\end{array}$ \\
\hline $\begin{array}{l}\text { Methopvrapone } 3 \mathrm{~g} . \\
\text { daily }\end{array}$ & $\begin{array}{l}17 \mathrm{KS} \\
17 \mathrm{OHCS}\end{array}$ & $\begin{array}{l}0.4 \\
7.8\end{array}$ & $\begin{array}{l}0.5 \\
3.0\end{array}$ & & $\begin{array}{l}\mathrm{mg} . / \\
24 \text { hours }\end{array}$ \\
\hline
\end{tabular}


The results of specific biochemical investigations are shown in Table 1 and 2.

Urinary $17 \mathrm{KS}$ were estimated by the method of the M.R.C. Committee on Clinical Endocrinology (1951) and urinary 17-hydroxycorticosteroids by the method of Appleby, Gibson, Norymberski and Stubbs, (1955). A standard ACTH test (Renold, Jenkins, Forsham and Thorn, 1954) was performed, measuring urinary steroids on the third, fourth and fifth day after commencement of an intravenous infusion of ACTH, 80 units on each of three consecutive days. An increase of 50 per cent in urinary corticoids is necessary to demonstrate a normal response (Thompson \& King 1959). The electrocardiographic changes in hypothyroidism and hypoadrenalism consist of reduction of amplitude of the $T$ waves in standard leads (usually less than $6 \mathrm{~mm}$. in leads $1+2+3)$; a diminished voltage of the QRS complexes in standard leads and in the anterior chest leads $(\mathbf{R} 1+2+3$ less than $25 \mathrm{~mm}$.).

The metyrapone (Methopyrapone, SU4885) test was performed by the method of Marks (1962) giving $3 \mathrm{~g}$. in divided doses by mouth daily for four days, and assaying urinary steroids on days four and five, this time being optimal for detecting the maximum rise. A metyrapone response of less than $10 \mathrm{mg}$./day (total $17 \mathrm{OHCS}$ ), or a rise of less than twice the basal levels, indicates a specific impairment of pituitary adrenal function, (Liddle, Island and Meador 1962; Marks and Summers, 1963).

\section{Discussion}

This lack of an adrenal response to intravenous ACTH, and the negative metyrapone tests indicated that the adrenal glands were incapable of a response to ACTH. This is probably a reflection of the long-standing atrophy of these glands consequent upon hypopituitarism of nearly sixteen years duration. Primary hypoadrenalism is excluded in this case by the absence of pigmentation taken together with the normal values of electrolytes on admission-at a stage when the patient was in coma. The tests of thyroid function were at the lower limit of normal in this patient, indicating that there was a relatively disproportionate degree of adrenal and gonadal hypofunction compared with thyroid function. Similar cases have been described by Sheehan (1961). These findings in conjunction with the striking clinical features of secondary hypogonadism leave no doubt that this patient suffers from hypopituitarism.

The history clearly points to a postpartum necrosis of the gland as the underlying cause. The detailed clinicopathological findings and variants of postpartum necrosis of the pituitary have been described by Sheehan and his colleagues (Sheehan and Summers, 1949, 1952, Sheehan, 1954, 1958, 1961, Sheehan and Stanfield, 1961, and Sheehan and Whitehead, 1963), and the clinical signs in this patient closely correspond to these descriptions. Of the tests available for the assessment of the integrity of the pituitary-adrenal axis, the metyrapone test is generally agreed to be the most sensitive in the detection of minimal dys- function (Brownie and Sprunt, 1962; Marks d Summers, 1963). The negative metyrapone sponse in the present patient is indicative क्वof impairment of pituitary-adrenal function and the failure of the adrenal response to endogenews ACTH was paralleled by a similar negative pesponse to exogenous ACTH. The pathologyoof these cases has until recently been ill-defin $\bar{d}$, but it is of interest that Sheehan and Whiteh $\overline{\text { eid }}$ (1963) have recently demonstrated that in cakes of postpartum pituitary necrosis who died within 35 days of 'delivery', a clear relationship exists between the severity of the necrosis of the anteridr lobe and the occurrence of vascular lesions in the neurohypophysis. It is postulated that prolongd vascular spasm produces damage to vessels in 由le stalk, and that the subsequent re-establishment of a blood flow produces thrombosis in these vessels, which, if extensive, might lead to damange to the posterior lobe on rare occasions. By contrast in the late cases, examined many years af erer postpartum necrosis of the anterior lobe bुs occurred, the neural stalk shows no recognisable lesions, but atrophy or scarring are seen faequently in the posterior lobe. Sheehan and Whitehead believe that there is no evidence that the acute lesions seen occasionally in the posterwor lobe lead to the more commonly found lesigis in late cases.

A meningitic picture as the presenting fegture of hypopituitary coma has been reported io literature (Sheehan, 1958; Wilson, 1953; Caushey and Garrod, 1954). The most detailed accou tuis that of Blau and Hinton (1960), but even this account lacks full biochemical confirmation of the pituitary hypofunction. Sheehan (1958) loigs divided cases of hypopituitary coma into toro distinct groups: a spastic type, and a flaccid tyße. In the former, the arms and legs are rigid a ad flexed in the fœtal position, the neck is stiff and the reflexes may be brisk, with a Babinski 吾sponse. Muscular twitching is seen in the face and arms on occasions. The flaccid type is charaxeterised by diminished or absent tendon reflexês, dilated pupils, and double incontinence. The patient described in this paper most closely sembles the spastic type, yet the absent reflexes in the legs, and flexor plantar responses cleagy indicate that some overlap occurs between thesse two groups. and the distinction is probably an artificial one.

Cases of the type described above could easily be confused with pituitary apoplexy, in which signs of meningeal irritation may be prominent and so mimic a ruptured aneurysm (Brain, 1962 ). Other conditions to be considered in the diffetyential diagnosis are subarachnoid hæmorrhage, in which the onset is usually more abrupt and headache more severe, cerebral infarction in which focal signs are more prominent and cereb. abscess in which the onset is insidious and in which apathy is more usual than coma, and foegal signs and a source of infection are commondy 
apparent. Encephalitis may produce similar meningitic signs and impaired consciousness; however, the onset is usually more gradual and a pleocytosis is found in the cerebro-spinal fluid. We can offer no satisfactory explanation for the signs of meningism, and the mechanism remains obscure.

It is often difficult to determine the precipitating factor in hypopituitary coma. In the present case it is suggested that an upper respiratory infection was the provocative factor in the absence of other commonly implicated precipitants.

The patient responded to empirical therapy without specific replacement of corticosteroids or thyroid analogues. The electroencephalogram recorded after the intial stage of coma showed persistent theta activity at five to seven cycles per second with a peak amplitude of 100 microvolts and delta activity at three to four cycles per second of similar amplitude, predominant in the anterior regions. These changes did not disappear on visual attention and are similar to those reported by Hughes and Summers (1956) in hypopituitarism. Specific replacement therapy has been reported to produce improvement in the EEG appearance according to Boselli and Jefferson (1957). These EEG changes, though typical, are not specific and therefore are not of diagnostic value.

In obscure cases of coma with meningitic signs, hypopituitarism must be considered in the diagnosis especially since specific replacement therapy may be life-saving.

\section{Summary}

A patient with Sheehan's syndrome is described, who presented with an illness characterised by both coma and severe meningism. The diagnostic problem posed by such cases is discussed, and the investigations and literature are reviewed.

\section{REFERENCES}

Allotr, E. N., and Simmons, J. H. (1951: Effect of Cortisone on Crisis in Simmond's Disease, Brit. med. J., ii, 568.

Appleby, J I., Gibson, G., Norymberski, J. K., and StubBS, R. D. (1955): Indirect Analysis of Corticosteroids. Biochem. J., 60. 453.

Blau, J. N., and Hinton, J. M. (1960): Hypopituitary Coma and Psychosis, Lancet, i, 408.

BOSELl, F., and JeFFerson, A. A. (1957): Electroencephalogram With Chromophobe Adenomata and Rathke Pouch Cysts: Modification by Associated Metabolic Disorders, Electroenceph. clin. Neurophysiol., 9, 275.

Brain, W. R. (1962): 'Recent Advances in Neurology and Neuropsychiatry'. Seventh Edition, p. 90, London: Churchill

Brownie, A. C., and Sprunt, J. G. (1962): Metopirone in the Assessment of Pituitary-Adrenal Function, Lancet, i, 773 .

Caughey, J. E., and Garrod, O. (1954): Coma and Allied Disturbances of Consciousness in Hypopituitarism. Brit. med. J., ii, 554.

Caughey, J. E. (1958): In Modern Trends in Endocrinology. Ed. Gardiner Hill. p. 132, London: Butterworth.

FARQuHARSON, R. F. (1950): 'Simmond's Disease'. Springfield, Illinois: Charles C. Thomas.

Hughes, R. R., and SUmmers, V. K. (1956): Changes in the Electroencephalogram Associated with Hypopituitarism Due to Post Partum Necrosis, Electroenceph. clin. Neurophysiol., 8. 87.

Ingraham, F. D., Matson, D. D., McLaurin, R. L. (1952): Cortisone and ACTH as an Adjunct to the Surgery of Craniopharyngiomas, New Engl. J. Med., 246, 568.

LidDLE, G. W., IsLAND, D., and MEADOR, C. K. (1962): Normal and Abnormal Regulation of Corticotrophin Secretion in Man, Recent Progr. Hormone Res., 18, 125.

MARKS, V. (1962): Assessment of Pituitary Reserve by Metopirone, Lancet, i, 1409.

MArKS, V., and SUmmers, M. (1963): Pituitary-Adrenal Function in Cases of Pituitary Tumour, Brit. med. J., ii, 155.

M.R.C. Committee on Olinical Endocrinology (1951): Proposed Standard Method of 17-Ketosteroid Determination, Lancet, ii, 585 .

Perkins, R. F., and Rynearson, E. H. (1952): Practicae Aspects of Insufficiency of the Anterior Pituitary Gland in the Adult, J. clin. Endocrin., 12, 574.

Renold, A. E., Jenkins, D., Forsham, P. H., and Thorn, G. W. (1952): The Use of Intravenous ACTH: A Study in Quantitative Adrenocortical Stimulation, Ibid., 12, 763.

Sheehan, H. L., and Summers, V. K. (1949): The Syndrome of Hypopituitarism, Quart. J. Med., $18,319$.

SHeEhan, H. L., and Summers, V. K. (1952): Treatment of Hypopituitary Coma, Brit. med. J., i, 1214 .

SHeEhan, H. L. (1954): The Incidence of Post Partum Hypopituitarism, Amer. J. Obstet. Gynec., 68, 203.

SHEeHAN, H. L. (1958): Le Coma Hypopituitaire, Extrait J. Marseille Medical, 7, 1.

Sheehan, H. L., and Stanfield, J. P. (1961): The Pathogenesis of Post Partum Necrosis of the Anterior Lobe of the Pituitary Gland, Acta Endocrin., 37, 479.

Sheenan, H. L. (1961): Atypical Hypopituitarism, Proc. roy. Soc. Med., 54, 43. Sheehan, H. L., and Whitehead, R. (1963): The Neurohypophysis in Post Partum Hypopituitarism, J. Path.
Bact., 145. Thompson, R. H. S., and KING, E. J. (1959): 'Biochemical Disorders in Human Disease.' p. 258. London:
Churchill.

WilsoN, L. A. (1953): Pituitary Insufficiency in Women, Lancet, i, 203. 